\title{
A Clinically Intriguing Case of One Sided Axillary Lipoma and Other Sided Axillary Hidrocystadenoma in the Same Patient- Case Report
}

\author{
Tandon N, Srivastava AN and Tiwari $\mathrm{N}^{*}$ \\ Department of Pathology, Eras Lucknow Medical College and Hospital, India
}

${ }^{*}$ Corresponding author: Tiwari N, Dept. of Pathology, Eras Lucknow Medical College and Hospital, India, Tel: 09839095880,E-mail: nehaneemat@yahoo.co.in

Citation: Tandon N, Srivastava AN, Tiwari N (2017) A Clinically Intriguing Case of One Sided Axillary Lipoma and Other Sided Axillary Hidrocystadenoma in the Same Patient- Case Report. SAJ Case Reports 4: 403

Article history: Received: 04 October 2017, Accepted: 28 November 2017, Published: 30 November 2017

\begin{abstract}
Eccrine Hidrocystadenomas are rare, benign cystic lesions and they occur predominantly on the face usually seen on the eyelids. They have a chronic course and vary with season. These are benign cystic lesions unlike hiradenomas, which are solid tumors. These arise in the eccrine sweat glands which are oil secreting glands. Normally these are more common in apocrine glands. They are also called Cysts of Moll or Sudiriferous cysts. We came across a similar case of eccrine hidrocystadenoma on one side of axilla and co existing large lipoma on the other sided axilla in a 30yr old female patient. She was taken up for surgery and kept under follow-up for one month. We present this case as it's interesting to see two isolated benign lesions in one patient occurring at the same time. As far as we have searched until now no case with such presentation has been reported.
\end{abstract}

Keywords: Eccrine; Hydrocystadenoma; Lipoma

\section{Introduction}

Hidrocystadenomas are rare cystic lesions of sweat glands, usually in the head and neck regions commonly seen on the eyelids [1]. They are not solid tumors (a similar sounding lesion called hidroadenoma is a benign solid tumor). There are three types of "sweat" glands: True sweat glands or eccrine glands, sebaceous glands which have an oily secretion around hair follicles and apocrine glands which have more oily product than eccrine glands and are found on the face, armpit and groin. Hidrocysadenomas usually arise from apocrine glands. They are also called Cysts of Moll or sudoriferous cysts. Lipomas are another group of benign lesions which are commonly subcutaneous or superficial and composed of mature adipose tissue separated by thin septae. These tumors can be admixed with areas of spindle cells or vascular proliferation and are typed accordingly. However, when occurring they can be single or multiple just like hidrocystadenomas, however, co-occurrence of two benign lesions totally indistinct occurring simultaneously is intriguing. Here we report a case of eccrine hidrocystadenoma in the axillary region with a coexisting lipoma on the other side of the axilla in a 30yr old female.

\section{Case History}

A30yr old female presented to the surgery OPD with complaints of bilateral axillary swellings since 8yrs. The swellings were initially pea-sized and nonprogressive. They started increasing in size for the past 3yrs and for the past one year it had become extremely painful. No other significant history was found.

The bilateral axillary swelling, the largest was approx. $6 \times 3 \mathrm{~cm}$ in size tender, and compressible, not fixed to the underlying structures or overlying skin. The swellings after surgery were sent to the pathology department of ELMC\&H.

Gross findings showed 2 grayish-white soft tissue pieces, one solid and the other solid with the cystic area. The larger piece measured $6 \times 5 \times 2.5 \mathrm{~cm}$ with attached skin ellipse measuring $4 \times 5.5 \mathrm{~cm}$. On cut surface, grayish white solid areas were seen and cut section through the cystic piece showed cavity filled with watery fluid. The cut surface of the solid tissue piece was yellowish 
white. Representative sections were taken and stained with HnE. Microscopically the cystic tissue shows tissue lined by squamous epithelium. The underlying dermis shows fibrocollagenous and fibrofatty tissue (Figure 1). Dermis also shows cystic lesions which are lined with two layers of small, cuboidal epithelial cells. In some areas, only a single layer of flattened epithelial cells seen and their flattened nuclei extending parallel to the cyst wall seen. The section also shows unremarkable skin appendages. The sections from another side of axillary swelling show lobules of mature adipocytes with intervening fine fibrous septa containing thin-walled blood vessels. No special stains were performed due to straightforward diagnosis. A diagnosis of eccrine hydrocystadenoma was made for the swelling in the one side axilla while lipoma was diagnosed for the swelling on the other side (Figure 2). Patient consent was taken before publication.

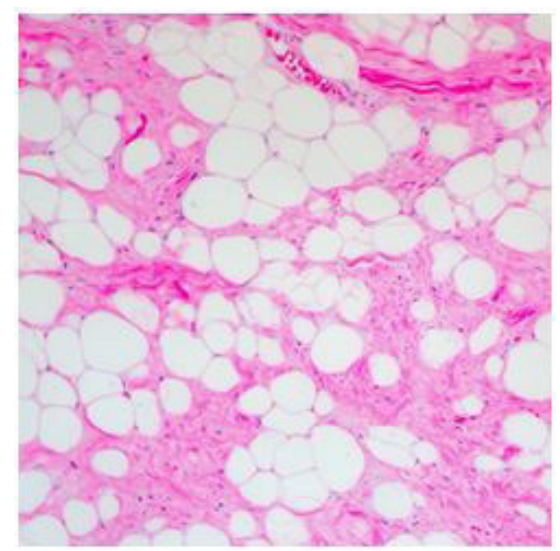

Figure 1: 10X Showing mature adipose tissue with intervening fibrocollagenous septae

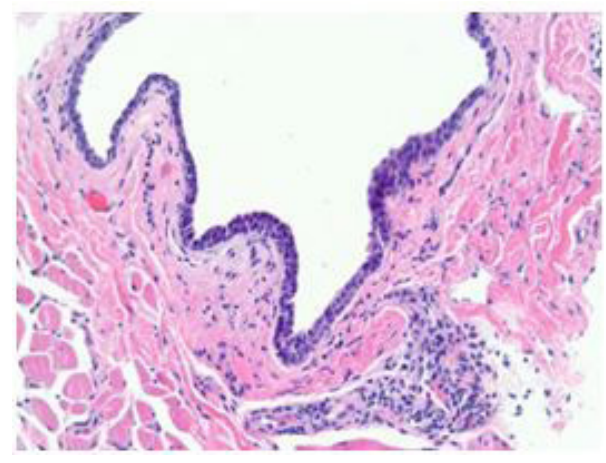

Figure 2: 40X Eccrine hydrocystadenoma

\section{Discussion}

Hidrocystadenomas most commonly found in the head and neck region, whether eccrine or apocrine are benign lesions of the sweat glands. They occur predominantly in the face and malar region. They occur more commonly in females and are usually small 1-6mm in diameter, tense thin-walled cysts, occurring as single or multiple lesions [1]. Apocrine hidrocystadenomas arise from the proliferation of apocrine glands and are usually solitary, measuring 3 to $15 \mathrm{~mm}$ in diameter [1]. Most common site of occurrence of these lesions is the head and neck region and around the lid margin near the inner canthus of the eye [2]. Eccrine lesions are more likely than apocrine lesions to occur at periorbital regions. The general distribution of lesions tends to occur in similar locations on the body for both the hidrocystadenomas [1]. Eccrine hidrocystadenomas are rare, benign, cystic lesions occurring predominantly on the face, and associated with a chronic course and seasonal variation. Lipomas are another group of benign lesions which are commonly subcutaneous or superficial and composed of mature adipose tissue separated by thin septae. These tumors can be admixed with areas of spindle cells or vascular proliferation and are typed accordingly. However, when occurring they can be single or multiple just like hidrocystadenomas however co-occurrence of two benign lesions totally indistinct occurring simultaneously is intriguing. Differentiation from apocrine hidrocystadenomas poses a problem both clinically and histologically. Apocrine hidrocystadenomas are often larger, darker blue in color and less likely to be periorbital [3]. On histological examination, eccrine hidrocystadenomas which are lined by ductal cells differ from apocrine hidrocystadenomas by the absence of decapitation secretion, PAS-positive granules and myoepithelial cells. Eccrine hidrocystadenomas are generally unilocular whereas apocrine hidrocystadenomas are usually multilocular [3]. A controversy exists whether eccrine hidrocystadenomas are rare or not [4,5].

These are rare and usually asymptomatic and are often of interest to physicians of different specialties. The close resemblance of these lesions to serious skin disorders such as basal cell carcinomas necessitates an understanding of the histology of each type of hidrocystadenoma for the purposes of differential diagnosis. In this case we came across an interesting case of eccrine hidrocystadenoma in a rare location like the axilla co-occurring with another isolated benign lesion, a large lipoma, on the other sided axilla, a deviation from its normal pattern. 


\section{Conclusion}

Clinically, it is important to differentiate eccrine hidrocystadenomas from another cyst like lesions like sebaceous and epidermal inclusion cysts, mucin cysts, hemangiomas and lymphangomas and pigmented cystic type of basal cell carcinomas [6,7]. A biopsy of the lesion is necessary to exclude these diagnosis. Hidrocysadenomas of the ear is very rare however they occur and pose a problem for cosmetic as well as functional activity [8]. They are cosmetically undesirable as a result of their predominant facial location. The treatment of multiple eccrine hidrocystomas remains a challenge. The effect of atropine is variable and aggressive surgical excision may lead to scarring [7].

\section{References}

1. Miyamoto T, Yhagari, T, Watanabe, T Yoshino (2005) Axillary apocrine carcinoma with benign apocrine tumours: a case report involving a pathological and immunohistochemical study and review of the literature. J Clin Pathol 58: 757-61.

2. Alfadley A, Al Aboud K, Tulba A, Mazen M (2001) Multiple eccrine hidrocystomas of the face. Int J Dermatol 40: 125-9.

3. Kaur C, Sarkar R, Kanwar AJ, Mohan H (2002) Multiple eccrine hidrocystomas. J Eur Acad Dermatol Venereol 16: 288-90.

4. Gupta S, Handa U, Handa S, Mohan H (2001) The efficacy of electrosurgery and excision in treating patients with multiple apocrine hidrocystomas. Dermatol Surg 27: 382-4

5. del Pozo J, García-Silva J, Peña-Penabad C, Fonseca E (2001) Multiple apocrine hidrocystomas: treatment with carbon dioxide laser vaporization. J Dermatolog Treat 12: 97-100.

6. Blugerman G, Schavelzon D, D’Angelo S (2003) Multiple eccrine hidrocystomas: a new therapeutic option with botulinum toxin. Dermatol Surg 29: 557-9

7. Ascherman JA, Knowles SL, Troutman KC (2002) Extensive facial clefting in a patient with Goltz syndrome: multidisciplinary treatment of a previously unreported association. Cleft Palate Craniofac J 39: 469-73

8. Lara-Sánchez H, Vallejo-Valdezate LA, Zegarra-Molina M, Madrigal Rubiales B, Zamora-Martínez T, et al. (2013) Eccrine Hidrocystoma in the Middle Ear Associated With a Preauricular Fistula. Otol Neurotol 34: e109-10. 